Silesian University of Technology

Aly A. Hamouda

University of Stavanger

Renata Cicha-Szot, Grzegorz Leśniak, Piotr Kasza, Klaudia Wilk

Oil and Gas Institute - National Research Institute

\title{
Research Project: "Design, environmental impact and performance of energized fluids for fracturing oil and gas reservoir rocks of Central Europe" (ENFLUID) - assumptions, evolution and results
}

The main goal of the project, realized by the Silesian University of Technology (as the Project Promotor), Oil and Gas Institute - National Research Institute and University of Stavanger, was the development of energized fracturing fluids for use in oil and gas reservoir formations in Central Europe. Transferring the American or foreign experience was not the solution, and already known methods may require modification or development. This has become important in the case of European gas shales, reservoir potential of which were the subject of intensive diagnosis when the project was launched. Within the framework of the project, composition of energized fracturing fluid for work in different formations of Central Europe was designed, mutual interactions between the fluids and the fractured rock were defined, the effects of energized fluids application on the geochemistry of the formation in the short and in the long-term were determined and the methods of treatment and recycling of flowback water were proposed. The project was focused on innovative technology, allowing for an efficient development of conventional and unconventional gas reservoirs, combined with maximum reduction of the negative impact of this process on the natural environment. The project also facilitated the strengthening and sharing of knowledge based on the fields of research and technological topics and issues of unconventional shale reservoirs.

Key words: hydraulic fracturing, unconventional gas reservoir, flowback water, gas-rock-water interactions.

Projekt badawczy: "Projektowanie, wpływ na środowisko i skuteczność działania energetyzowanych cieczy do szczelinowania skał zbiornikowych ropy i gazu Europy Środkowej" (ENFLUID) - założenia, przebieg i rezultaty

Głównym celem projektu „ENFLUID”, realizowanego przez Politechnikę Śląską (w roli Koordynatora), Instytut Nafty i Gazu Państwowy Instytut Badawczy oraz Uniwersytet Stavanger, było opracowanie optymalnego składu energetyzowanych cieczy szczelinujących, przydatnych do zastosowania w złożowych formacjach ropy i gazu Europy Środkowej. W tych specyficznych warunkach bezpośrednia adaptacja technologii i doświadczeń zagranicznych nie jest właściwym rozwiązaniem, a znane metody szczelinowania mogą wymagać modyfikacji lub rozwinięcia. Ma to szczególne znaczenie w przypadku łupków gazonośnych, których potencjał złożowy jest przedmiotem intensywnego rozpoznania. W ramach projektu opracowano skład energetyzowanych cieczy szczelinujących odpowiednich do zastosowania w różnych formacjach złożowych, zdefiniowano wzajemne interakcje pomiędzy cieczami a skałą poddawaną szczelinowaniu, określono jakie są skutki stosowania energetyzowanych cieczy szczelinujących na środowisko geochemiczne formacji w krótkim i długim okresie czasu oraz zaproponowano metody neutralizacji oraz recyklingu płynów zwrotnych ze szczelinowania. Realizacja projektu pozwoliła na stworzenie innowacyjnej technologii, ukierunkowanej na efektywne wykorzystanie konwencjonalnych i niekonwencjonalnych złóż gazu i ropy zamkniętych w formacjach złożowych Europy Środkowej, przy równoczesnej minimalizacji negatywnego wpływu tego procesu na środowisko naturalne.

Słowa kluczowe: szczelinowanie hydrauliczne, niekonwencjonalne złoża gazu, płyn zwrotny, interakcje gaz-skała-woda. 


\section{Introduction}

In September 2012, The National Centre For Research and Development as Programme Operator of the Polish-Norwegian Research Programme implemented under the Norwegian Financial Mechanism 2009-2014, announced the Core 2012 Call for proposals. It focused on 5 thematic areas including "Environment", with total funding of $159 \mathrm{mln}$ PLN. Within the framework of the Call project: "Design, environmental impact and performance of energized fluids for fracturing oil and gas reservoir rocks of Central Europe" (ENFLUID) was prepared. The consortium consisted of: Silesian University of Technology (SUT) as the Project Promotor, University of Stavanger (UiS) and Oil and Gas Institute - National Research Institute (OGI - NRI).

Submitted within the Call, were 269 projects that applied for funding amounting to nearly $942 \mathrm{mln}$ PLN. In March 2013 the ranking of projects recommended for co-funding was presented. Topping the list was the project "ENFLUID", which amounted to 4062628 PLN [8].

The project fitted the scope of the „Environment” priority of the Polish-Norwegian Research Programme. It was focused on innovative technology, allowing for an efficient development of conventional and unconventional gas reservoirs, combined with maximum reduction of the negative impact of this process on the natural environment.
The detailed thematic priorities were closely connected with the research object:

- rational use of natural resources, including rational water management - energized fluids allows for more efficient usage of gas resources, with minimized amounts of water for fracturing,

- recycling technologies - $\mathrm{CO}_{2}$ comes from capturing processes, because $\mathrm{CO}_{2}$ flows out of the well as a gas, even if mixed with water, there is less water to recover. Excessive water flowback leads to more costs of reuse, or disposal,

- technologies of new and renewable energy sources - development of unconventional gas and oil resources can provide new energy sources for Europe,

- technologies that impact limiting of greenhouse gases and aerosols - application of $\mathrm{CO}_{2}$ for fracturing unconventional formations minimizes atmospheric emissions only to a minor extent, but enabling usage of unconventional gas instead of the coal, is key for $\mathrm{CO}_{2}$ and particulates emissions abatement in Central Europe,

- technologies of carbon capture and storage (CCS) $-\mathrm{CO}_{2}$ geological storage efficiency (eg. injectivity of a formation) - may depend on fracturing jobs, which are enhanced by the application of energized fluids, which are intended to be developed and tested in different conditions within this project [4].

\section{Project description}

The main goal of the project, that started in June 2013 and ended in April 2016, was the development of energized fracturing fluids for use in oil and gas reservoir formations in Central Europe. Intensification of reservoirs is made possible by the use of hydraulic fracturing. Hydraulic fracturing is an engineered propagation of fractures in hydrocarbons reservoir rock by means of fluids injected at high pressure and huge volume into a well. The formed fractures are kept open, due to the injected material like sand, enabling the fluid flowback and later the flow of oil and gas into the well. Fracturing is essential for the production of formerly inaccessible hydrocarbons from low permeability formations. When the fracturing fluid is water-based, so called formation damage may occur, due to swelling of clay minerals or other physical and chemical mechanisms. Minimization of the damage is possible due to partial or complete substitution of water by gases. Fracturing fluids prepared in such a way are called energized fluids. Injection of $\mathrm{CO}_{2}$ - based energized fluids may also enhance hydrocarbons recovery from a well, allowing for carbon dioxide storage in the geological formation at the same time. The energized fracturing fluid (in the form of foam) should be a stable mixture of liquid and gas. In order to produce such stable mixtures, surfactants are applied, that concentrate at the gas/liquid interface and reduce the surface tension between the phases. The surfactant stabilizes the thin liquid film and prevents the merging of bubbles of gas.

This project addressed the following issues of the energized fracturing fluids:

- how can we use the petrophysical, mineralogical, petrological and geochemical analyses in formulating the criteria screening of the energized fluid fracturing and enhanced oil recovery - realized in Work package 1 (WP1); responsible entity: OGI - NRI,

- what should be the composition of energized fracturing fluid for work in different formations of Central Europe - realized in Work package 2 (WP2); responsible entity: OGI - NRI,

- what are the effects of energized fluids application on the geochemistry of the formation in the short and in the long-term - realized in Work package 3 (WP3); responsible entity: SUT,

- what are the mutual interactions between the fluids and the fractured rock - realized in Work package 4 (WP4); responsible entity: UiS, 
- what is the impact of designed energized fracturing fluids on the formation damage - realized in Work package 5 (WP5); responsible entity: $\mathrm{UiS}$,
- how can the backflow resulting from the designed fluids application be treated or recycled - realized in Work package 6 (WP6); responsible entity: SUT [8].

\section{Results}

Within the WP1, samples from four main types of reservoir rocks were selected (over 30 from Carpathian sandstones, 52 from Rotliegend sandstones, about 20 from main dolomite and about 20 from Silurian shales) and initial and basic petrophysical analyses were performed. All selected samples were examined using standard petrophysical methods (mercury injection, steady state permeability measurement). Moreover, in order to determine the applicability of various mathematical models to estimate porosity and permeability, for samples of the Rotliegend sandstones with distinct laminae of thicker grains, a selection of specialized analyzes were carried out $[1,6,7]$. Permeability tests were carried out on plug type samples which were also used for CT, nano CT and XRMI investigations. In order to obtain a reliable rock model with the distinction of skeletal grains and cement for every sample, mineralogical and petrographical analysis were performed. Moreover, digital microscopic images analysis was applied for pore space characterization. For samples representing the main dolomite and Silurian shales, geochemical TOC and Rock Eval analysis were carried out. Based on petrophysical parameters and wettability index, screening criteria for $\mathrm{CO}_{2}$ enhanced oil recovery $\left(\mathrm{EOR}-\mathrm{CO}_{2}\right)$ were developed. After interaction of the fracturing fluid with rock sample, a petrographical and SEM analysis were performed which allowed to determine its influence on the rock skeleton and cement. In order to determine fracturing fluids preparation conditions in WP2, a series of tests such as: selecting the type and amount of the individual components of the fluid and determining the conditions of its preparation (order, method of dispensing and mixing) were conducted. The composition of technological fluids using polymers with additives such as: scale inhibitor, clay minerals inhibitor, nanoemulsion, foaming agent, biocide for energized fluids with $\mathrm{CO}_{2}$ and with $\mathrm{N}_{2}$ was prepared. The composition of technological fluids was designed based on the results of the following tests: fluid compatibility and stability tests, capillary suction time (CST) - tests of impact of fracturing fluids on clay minerals in rocks. Laboratory tests of surface tension, contact angle of the prepared fracturing fluids were carried out. The possibility of using UV light to protect fracturing fluids against the growth of bacteria and destruction of the polymer was tested. Tests of selected antimicrobial products on rheometer and foam generator were carried out. The study included changes in viscosity and the structural strength of foam with increasing temperature.
Physical properties of prepared systems like: foam quality, foam stability-half-life, bubble size distribution and foam texture, were carried out for each modified energized fracturing fluid. Proppant damage in the fracture and leak off parameters under dynamic and static conditions were evaluated. Based on tests results of damage to the fracture was determined for non-energized fracturing fluids as well as with the addition of nitrogen. Performed tests allowed to find suitable fluids for different, selected in WP1, formations [11, 12].

In the WP3 experiments and kinetic modeling of fluidrock-gas interactions simulating the conditions of fracturing the reservoir rocks, represented by the examined samples were performed. The experiments for determining the impact of $\mathrm{CO}_{2}$-based energized fracturing fluid on the rock samples were conducted to reproduce the geochemical interactions of fracturing fluid, and to obtain simulated fluids, of chemical composition as similar as possible to the flowback from fracturing unconventional formations, which further was utilized in recycling experiments in WP6. The XRD, SEMEDX analyses of rocks before and after experiment were compared, and revealed changes in the mineralogy and structure of the examined rocks. Chemical analyses of fracfluid and flowback demonstrated intensive interaction of fluid with the fractured rock. Geochemical modeling of the reactions in fracturing fluid-rock systems using The Geochemist's Workbench 10 (GWB 10) software tool, was carried out. Modeling was performed assuming the formation pressure at hydrostatic regime. Temperature values were estimated on the basis of measurements and archival well data, provided from the WP1. System temperature and $\mathrm{CO}_{2}$ fugacity were representative of the reservoir conditions. Chemical composition of the fracturing fluid, and mineralogy of formation rocks included in the modeling, was set according to the information received from WP2 and WP1 respectively. The kinetic rate constants for the minerals involved in the modeled reactions were taken from literature, and recalculated for the formation temperatures, according to Arrhenius law. The results of modeling gave the idea of possible reactions and structural, mineralogical changes in the fracfluid-rock systems and have the capacity of predicting the secondary mineral assemblages composition of flowback fluid after hydraulic fracturing [3].

The main goal of WP4 was to address shale fracturing fluid performance. 
In WP4, the following general outcomes were achieved:

- developed a new approach for fracturing shale. Injection of slug fracturing fluid energized by super critical $\mathrm{CO}_{2}\left(\mathrm{scCO}_{2}\right)$,

- multi rate injection, appeared to be efficient in reducing possible formation damage.

In addition it was shown that removing $\mathrm{O}_{2}$ from the injected $\mathrm{CO}_{2}$ also reduced the possibility of formation damage especially in the case where, iron sulfide minerals are present [2].

In the WP5 the fracturing fluids developed within WP2 were tested for interaction with clay minerals by determining the swelling index and swelling pressure. FTIR-ATR analysis of samples after swelling were performed. Those results confirmed the presence of secondary minerals after the contact with the fracturing fluid, which may suggest possible formation damage mechanism. Moreover, invasion damage zones at different reservoir rocks (external/internal filtercake, filtrate invaded zone) were determined. To evaluate formation damage of shale rocks, a prototype apparatus was developed. Furthermore, the tests aimed at assessing the degree of damage to well-adjacent zone, caused by energized fracturing fluids produced in WP2.
Core material was sampled and prepared, geological information were collected, test apparatus was modified for performing formation damage tests with the use of energized fracturing fluids. An analysis of the pore space of the cores after testing, using SEM and UV light, as well as permeability and porosity tests, was used to assess the possible damage to the rock by technological fluids [10].

The main objective of WP6 was to propose a treatment method for reuse and utilization of flowbacks produced when using energized fracturing fluids. The composition of the fracturing fluids and flowbacks was determined in WP6. The effect of the flowback on the aquatic and soil environment was assessed. A flexible system for the treatment of flowback was proposed. The system consists of micro/ultrafiltration, nanofiltration, activated carbon treatment, electrodialysis reversal, reverse osmosis, and is capable of treating both low salinity (TDS $<50 \mathrm{~g} / \mathrm{L}$ ) and high salinity flowbacks (TDS $>50 \mathrm{~g} / \mathrm{L}$ ). The elements of the system were tested in the laboratory; based on the results, the flow rates and ionic composition of the process streams, as well as overall treatment costs, were projected $[5,9]$.

\section{Summary}

The main goal of the "ENFLUID" project was the development of energized fracturing fluids for use in oil and gas reservoir formations in Central Europe. Despite much efforts, a lot still remains to be done in the area of energized fracturing of rocks typical for the Central European reservoirs. This project addressed the topic of the usage of petrophysical, mineralogical and geochemical analyses in formulating the criteria screening of the energized fluid fracturing and enhanced oil recovery. Research of the effects of energized fluids application on the geochemistry of the formation in the short and in the long-term, was helpful in the design of energized fracturing fluid for work in different formations of Central Europe. Additionally a flexible method of treatment and recycling of flowback fluid, was also proposed.

Please cite as: Nafta-Gaz 2018, no. 6, pp. 479-483, DOI: 10.18668/NG.2018.06.09

Article contributed to the Editor 23.12.2017. Approved for publication 22.03.2018.

The research leading to these results, has received funding from the Polish-Norwegian Research Programme operated by the National Centre for Research and Development under the Norwegian Financial Mechanism 2009-2014 within the framework of Project Contract No. Pol-Nor/196923/49/2013.

\section{Literature}

[1] Andrew M., Cicha-Szot R., Linden S., Such P., Leśniak G., Wiegmann A., Steinbach A.: Multiscale core to pore imaging and modelling of the Rotliegend Sandstone. $8^{\text {th }}$ International Conference on Porous Media \& Annual Meeting of the International Society of Porous Media Interpore, Cincinnati, Ohio 9-12.05.2016.

[2] Hamouda Aly A.: Interaction between slug fracturing fluids energized with $\mathrm{scCO}_{2}$ and shale minerals. Journal of Natural Gas Science and Engineering 2017, vol. 44, pp. 150-161.

[3] Labus K.: Lessons from successes and failures of batch experiments on gas-rock and energized fracturing fluid - rock interactions. Międzynarodowa Konferencja Naukowo-Techniczna Geopetrol 2014 „Poszukiwania i eksploatacja złóż ropy naftowej i gazu ziemnego - nowe technologie, nowe wyzwania”. Prace Naukowe INiG - PIB 2014, no. 198.
[4] Labus K., Cicha-Szot R., Leśniak G.: Projekt ENFLUID - między geologia a inżynieria złożowa. Materiały konferencyjne LXXXIII Zjazdu Naukowego Polskiego Towarzystwa Geologicznego „Wyzwania geologii regionu lubelskiego w XXI wieku", Biała Podlaska, 2014, pp. 27.

[5] Labus K., Kasza P., Turek M., Dydo P., Jakóbik-Kolon A., Wilk K., Leśniak G.: Laboratory experiments on forming the chemical composition of flowback brine from hydraulic fracturing with energized fluid. Procedia Earth and Planetary Science 2017, vol. 17, pp. 582-585.

[6] Leśniak G., Such P., Budak P.: Integration of petrophysical and petrographic data for the prediction of reservoir and filtration parameters in deep lying layers in Polish Rotliegend Basin. Conference Paper: International Symposium of the Society of Core Analysts, Avignon 2014, SCA 2014-Temp Paper A073. 
[7] Leśniak G., Such P., Cicha-Szot R., Steinbach A., Marsh M., Gelb J., Linden S., Wiegmann A., Glatt E.: Reservoir aspects of digital rock physics: A case study from the Polish Rotliegend basin. $7^{\text {th }}$ International Conference on Porous Media \& Annual Meeting of the International Society of porous Media Interpore, Padwa 18-21.05.2015.

[8] Lutyńska S.: Projekt ENFLUID krok po kroku. Biuletyn Politechniki Śląskiej 2014, no. 8/9, pp. 11-12.

[9] Turek M., Labus K., Dydo P., Mitko K., Laskowska E., JakóbikKolon A.: A concept of hydraulic fracturing flowback treatment using electrodialysis reversal. Desalination and Water Treatment 2017, vol. 64, pp. 228-232.

[10] Wilk K., Kasza P., Labus K.: Core analysis as a key to understanding formation damage after hydraulic fracturing treatment. Conference Paper: International Symposium of the Society of Core Analysts, Snowmass, Colorado, 2016, SCA2016-062.

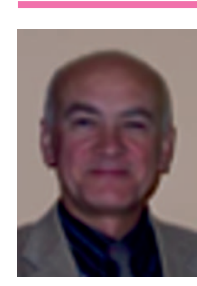

Prof. Marian Turek

Professor in Department of Inorganic Chemistry,

Analytical Chemistry and Electrochemistry

Faculty of Chemistry

Silesian University of Technology

ul. Akademicka 2A, Gliwice 44-100

E-mail: Marian.Turek@polsl.pl

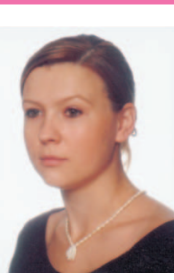

Renata CICHA-SZOT M.Sc. Eng.

Junior Scientist

Department of Petroleum Engineering

Oil and Gas Institute - National Research Institute

ul. Lubicz 25 A

31-503 Kraków

E-mail: renta.cicha@inig.pl

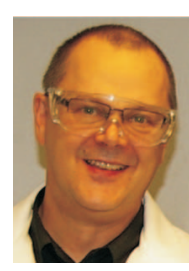

Piotr KASZA Ph.D. Eng.

Assistant Professor

Manager of Department of Production Stimulation

Oil and Gas Institute - National Research Institute

ul. Lubicz 25 A

31-503 Kraków

E-mail:piotr.kasza@inig.pl
[11] Wilk K., Kasza P., Labus K.: Analysis of the possibility for the applicability of energized fluids for fracturing. Nafta-Gaz 2015, no. 6 , pp. 425-433.

[12] Wilk K., Kasza P.: Zastosowanie płynów spienionych do zabiegów hydraulicznego szczelinowania. Przemysł Chemiczny 2016, vol. 95, no. 6, pp. 1202-1205.

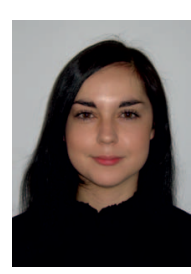

Sylwia LUTYŃSKA PhD. Eng.

Assistant Professor in Department of Applied Geology Faculty of Mining and Geology

Silesian University of Technology

ul. Akademicka 2A

Gliwice 44-100

E-mail: Sylwia.Lutynska@polsl.pl

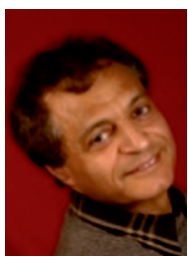

Prof. Aly A. HAMOUDA

Professor in Petroleum Engineering Department

University of Stavanger

Kitty Kiellands hus

Rennebergstien 30

4036 Stavanger, Norway

E-mail:aly.hamouda@uis.no

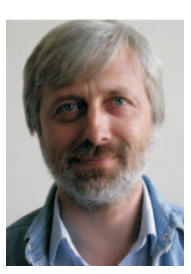

Grzegorz LEŚNIAK PhD. Eng.

Assistant Professor

Head of Department of Geology and Geochemistry

Oil and Gas Institute - National Research Institute

ul. Lubicz 25 A

31-503 Kraków

E-mail: grzegorz.lesniak@inig.pl

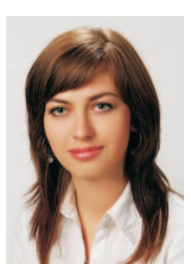

Klaudia WILK M.Sc. Eng.

Assistant, Department of Production Stimulation

Oil and Gas Institute - National Research Institute

ul. Lubicz $25 \mathrm{~A}$

31-503 Kraków

E-mail: wilkk@inig.pl 